\title{
KOMODIFIKASI TEKNIK CETAK SARING DI KAMPUNG WEDI, KLATEN
}

\author{
Nadiyah Tunnikmah *)
}

\begin{abstract}
ABSTRACK
The active use of screen printing techniques by industry sectors encourages this technique to be developed both in the use of tools or materials. It is undeniable that the use of screen printing techniques or so-called commercial screen printing makes this technique can be studied not only in formal educational institutions but also non-formal. The emerging of screen printing practitioners made this technique development specifically according to their individual needs. One of Commodification of screen printing techniques in the community is in dukuh Krangkungan, di Desa Pandes, Kecamatan Wedi, Kabupaten Klaten, Central Java. Characteristics that developed in Wedi researched using field methods of observation, documentation and interviews. Paguyuban as a place to communicate and socialize have a role to screen printing technique that exist in Wedi. The spirit of togetherness that is built in Paguyuban Kampung Sablon not only in the stage of running a business but also on various aspects besifat technically one of them is to divide the screen printing ability. Paguyuban also as a forum to exchange information about the technical, tools and materials. Paguyuban also encourages employees who have working experience as a screen printing and has mastered the technical screen printing to open screen printing services themselves. Seen from the number of members of the community that has grown from 9 at the beginning of established now become 15 units of screen printing. The screen printing unit developed will be able to survive one of them with improved quality, work ability and efficiency.

Key word: Screen Printing, Commodification, Sablon
\end{abstract}

\begin{abstract}
ABSTRAK
Penggunaan secara aktif teknik cetak saring oleh sektor industri mendorong teknik ini terus dikembangkan baik dalam penggunaan alat atau bahan. Tidak dapat dipungkiri penggunaan teknik cetak saring atau yang biasa disebut sablon secara komersial membuat teknik ini dapat dipelajari tidak hanya di lembaga pendidikan formal tapi juga non formal. Praktisi sablon yang akhirnya bermunculan juga mengembangkan teknik ini lebih spesifik sesuai dengan kebutuhan masing-masing. Komodifikasi teknik cetak saring di masyarakat salah satunya di dukuh Krangkungan, di Desa Pandes, Kecamatan Wedi, Kabupaten Klaten, Jawa Tengah. Karakteristik serta rekayasa teknik yang berkembang di Kampung Sablon Wedi diteliti menggunakan metode lapangan berupa observasi, dokumentasi dan wawancara. Paguyuban sebagai wadah untuk berkomunikasi dan bersosialisai mempunyai peran terhadap teknik sablon yang ada di Wedi. Semangat kebersamaan yang dibangun dalam Paguyuban Kampung Sablon tidak hanya dalam tahap menjalankan usaha tapi juga pada berbagai aspek yang besifat teknis salah satunya adalah membagi kemampuan menyablon.. Paguyuban juga sebagai wadah untuk bertukar informasi mengenai teknis, alat dan bahan. Paguyuban juga mendorong karyawan yang telah lama bekkerja sebagai tukang sablon dan telah menguasai teknis sablon utnuk membuka
\end{abstract}

\footnotetext{
* Nadiyah Tunnikmah (nadiyahtunnikmah@gmail.com), Staf Pengajar Jurusan Seni Rupa Murni Fakultas seni Rupa Institut Seni Indonesia Yogyakarta
} 
jasa sablon sendiri. Terlihat dari jumlah anggota paguyuban yang telah bertambah dari 9 pada awal didirikan sekarang menjadi 15 unit sablon. Unit sablon yang dikembangkan akan bisa bertahan salah satunya dengan peningkatan kualitas, kemampuan kerja dan efisiensi kerja.

Kata Kunci: Cetak Saring, Komodifikasi, Sablon

\section{PENDAHULUAN}

Cetak saring adalah teknik paling muda dalam sejarah seni grafis walau dipercaya teknik ini sudah digunakan di Cina dan Jepang pada tahun 500 dan 1000 S.M. Pada awalnya cetak saring atau yang biasa disebut sablon dikenal dengan nama silk screen karena bahan yang digunakan sebagai screen terbuat dari sutra. Saat cetak saring mulai banyak digunakan di Eropa pada awal abad 20, teknik dan perkembangan alat serta bahan berkembang dengan dinamis. (Jules, 1947).

Aplikasi cetak saring pada banyak media terutama tekstil membuat cetak saring cepat populer. Teknik ini semakin berkembang dengan pesat di abad ke 20 terutama untuk penggunaan industri periklanan. Pada tahun 1935 Anthony Velonis membuat proyek silkscreen dibawah naungan Works Progress Administration (WPA). Untuk pertamakalinya proses silkscreen menarik perhatian para seniman yang sebelumnya banyak menolak kemungkinan kreatif dari silkscreen disebabkan karakter komersial yang dimiliki silkscreen saat itu.

Sablon merupakan teknik yang populer dan masih dengan aktif digunakan di masyarakat termasuk sektor industri. Penggunaan secara aktif dari sektor industri mendorong teknik ini terus dikembangkan baik dalam penggunaan alat atau bahan. Tidak dapat dipungkiri penggunaan sablon secara komersial membuat teknik ini dapat dipelajari tidak hanya di lembaga pendidikan formal tapi juga non formal. Praktisi sablon yang akhirnya bermunculan juga mengembangkan teknik ini secara lebih spesifik sesuai dengan kebutuhan masingmasing.

Salah satu bukti dari bagaimana komodifikasi teknik cetak adalah munculnya sentra usaha sablon di dukuh Krangkungan, di Desa Pandes, Kecamatan Wedi, Kabupaten Klaten, Jawa Tengah. Wirausaha sablon yang berjumlah cukup banyak di Krangkungan membuat paguyuban yang akhinya dikenal di masyarakat umum dengan nama kampung Sablon Wedi.

Istilah kampung sablon sudah melekat dengan kuat pada kampung Wedi. Salah satu buktinya bisa dilihat dari mesin pencari elektronik berbasis google yang memperlihatkan ada 290.000 hasil dalam waktu 0,49 detik jika mengetikkan kata kampung sablon. Hasil pencarian teratas memperlihatkan alamat situs www.kampung-sablon.blogspot.com dengan alamat pada peta terletak di Dk. Krangkungan Rt/w 15/06, Pandes, Wedi, Jawa Tengah.

Dikalangan pegiat sablon nama kampung Wedi sebagai sentra sablon sudah mulai dikenal sejak tahun 1990an. Saat itu sablon khas Wedi yang dikenal adalah teknik cecek atau pointilis. Kemampuan sablon Wedi dikenal untuk jenis sablon basis air yang diaplikasikan pada kaos, jaket, jumper, kostum dan training olahraga, rompi, 
kemeja, sweater, blazer, celana, topi, dan masih banyak yang lainnya.

\section{METODE}

Metode dapat dipahami sebagai cara serta strategi untuk memahami realitas, langkah-langkah sistematis untuk memecahkan rangkaian, sebab akibat berikutnya. (Nyoman Kuntha Ratna 2010:84) Untuk mempermudah proses maka dalam penelitian meliputi batas penelitian, teknik pengumpulan data serta analisis data sesuai dengan tujuan dan fokus penelitian.

\section{a. Batas penelitian}

Objek penelitian ini dibatasi pada teknik sablon berupa penggunaan alat dan bahan pada paguyuban Kampung Sablon di dukuh Krangkungan, di Desa Pandes, Kecamatan Wedi, Kabupaten Klaten, Jawa Tengah.

\section{b. Teknik pengumpulan data}

Teknik pengumpulan data adalah tahapan dalam penelitian yang berkaitan dengan metode yang digunakan dalam pengumpulan data yang dibutuhkan. Ada dua metode lapangan yang digunakan yaitu: Metode Lapangan berupa observasi, dokumentasi dan wawancara: observasi dilakukan untuk mendapatkan data berdasarkan pengamatan terhadap teknik sablon yang dilakukan serta penggunaan alat dan bahan; Dokumentasi yang dilakukan berupa pencatatan tertulis, perekaman data gambar ataupun suara; Wawancara, dilakukan dengan sampel yang telah ditentukan sebelumnya dengan menggunakan pedoman wawancara, mendengarkan serta merekamnya dan kemudian menindaklanjuti dengan pertanyaan tambahan yang terkait; Sample dipilih berdasarkan keaktifan mennjadi anggota dan Kelengkapan unit usaha.

\section{c. Analisis data}

Proses analisis data dimulai dengan menelaah semua data yang tersedia dari berbagai sumber melalui pengunaan metode lapangan dan metode pustaka. Penelitian ini menempatkan kualitatif yang merupakan kualitas data, sebagai jenis penelitian atau jenis data yang dianalisis.

\section{HASIL DAN PEMBAHASAN}

\section{Paguyuban Sablon}

Ketua paguyuban kampung sablon Wedi saat ini Agus Nugroho yang merupakan salah satu pelopor sablon di dusun Wedi serta pendiri paguyuban mengenal sablon sejak tahun 1998. Awal mulai mengenal sablon dimulai dari pekerjaan sebagai tukang sablon di kota Klaten tepatnya di PT Mondrian.

PT Mondrian merupakan perusahaan garmen yang didirikan pada tahun 1992 terletak di Jl. Kh Hasyim Ashari no. 171 (By Pass) Klaten. Sebagai perusahan dengan skala besar dan sebagian besar produknya untuk ekspor. Industri garment dengan area kerja meliputi konveksi dan sablon dengan kapasitas produksi yang besar membuat PT Mondrian menjadi pabrik dengan banyak tenaga kerja. Penyerapan tenaga kerja dari PT Mondrian dibidang sablon juga tidak sedikit dan banyak tenaga kerja berasal dari Wedi.

Agus Nugroho mulai bekerja di PT Mondrian sejak 1998 sebagai tenaga sablon dan sejak saat itu berpindah-pindah sebagai tenaga sablon diberbagai kota seperti Yogya, Solo dan Pacitan. Pada tahun 2001Agus Nugroho bersama beberapa teman berinisiatif membuka usaha jasa sablon di 
dusun Wedi dengan nama usaha Wanted.Setelah beberapa tahun menjalankan usaha sablon bersama, pada tahun 2003 Agus Nugroho memutuskan membuka jasa sablon kaos sendiri. Usaha jasa sablon kaos berjalan dengn sukses dan mulai kewalahan dalam menerima order. Pada saat gempa tahun 2006 dampak pada usaha sablon adalah kacaunya proses produksi yang membuat Agus Nugroho kehilangan beberapa pelanggan.

Sesudah gempa, pada tahun yang sama usaha sablon mulai djalankan kembali dengan mengajak beberapa teman yang memang juga mempunyai usaha sablon untuk membuat paguyuban. Saat didirikan pada bulan Aguustus 2006 anggota paguyuban ada 5 unit usaha, hingga pada tahun 2015 anggota bertambah menjadi 15 unit usaha sablon, 7 diantaranya sudah menjadi unit usaha yang dilengkapi dengan konveksi untuk menjahit hasil sablon.

Penambahan unit usaha konveksi berdampak pada pengembangan kemampuan penyediaan jasa di kampung sablon Wedi. Saat belum ada konveksi proses produksi hanya pada wilayah sablon yang membuat ketergantungan cukup besar pada konveksi atau penjahit yang berada di luar Wedi. Konveksi yang dimiliki oleh beberapa anggota paguyaban juga menerima jasa jahit dari anggota paguyuban lain yang hanya memiliki unit sablon. Situasi ini membuat ketergantungan pada jasa jahit diluar Wedi berkurang dan resiko pengerjaan yang tidak tepat waktu bisa dikurangi.

Walau sudah menjadi paguyuban sejak tahun 2009 dan mempunyai AD/ART, Paguyuban Kampung Sablon belum terdaftar di Disperindag Klaten. Ini menunjukkan bahwa Paguyuban Kampung Sablon memang dikembangkan secara mandiri tidak ada pelatihan khusus sablon atau konveksi yang pernah diikuti atau diselenggarakan oleh pihak luar atau pemerintah untuk warga dusun Wedi. Kemampuan menjalankan usaha juga didapat secara non formal. Tanpa ada latar belakang pendidikan khusus karena memang sebagian besar anggota paguyuban merupakan lulusan SMA atau sederajat.

Semua anggota paguyuban masuk dalam kategori UMKM (Usaha Mikro Kecil Menengah). Kategori UKM sesuai dengan undang-undang no: 20 tahun 2008 tentang usaha Mikro, Kecil dan Menengah yaitu usaha produktif milik perorangan bukan anak cabang perusahaan. Secara spesifik unit usaha masuk dalam kriteria usaha kecil dengan kategori jasa dimana unit usaha sablon di kampung Wedi tidak membuat produk diluar pesanan pelanggan.

\section{Unit Sablon Wedi}

Seperti dijelaskan sebelumnya ada 15 anggota paguyuban, walau sebenarnya ada unit sablon lain di Wedi yang tidak masuk paguyuban. Kesamaan dari anggota paguyuban adalah proses sablon yang langsung dikerjakan oleh pemilik. Beberapa pemilik unit sablon di Wedi yang bukan anggota paguyuban tidak bisa menyablon sendiri sehingga proses sablon tergantung pada karyawan.

Tempat kerja atau unit sablon yang ada sebagian besar menjadi satu dengan rumah tinggal. Unit sablon yang menjadi satu dengan rumah tinggal mempunyai pembagian area kerja seperti area penyablonan, penyinaran dan pencucian screen yang tertata dengan baik.

Semua unit usaha sablon di Wedi menggunakan bahasa inggris sebagai nama usaha yaitu:

- FREEDOM, Pemilik Agus Nugroho. 
- KSR, Pemilik Sabdo Raharjo.

- SEIZE THE DAY, Pemilik : Fx. Heri Purwanto.

- TOP, Pemilik Iskandar.

- LANGgeng BUSONO, Pemilik Sunarno.

- HIKARU, Pemilik Muhammad Ali.

- THE KLIE WANT, Pemilik Adi Bawono.

- WARNING, Pemilik, Hendro Prasetyanto.

Unit sablon Agus Nugroho diberi nama Freedom dibuat sejak unit sablon Wanted yang didirikan bersama teman bubar dan masing-masing mendirikan unit sablon sendiri. Agus Nugroho sendiri sekarang hanya mempunyai unit sablon tanpa konveksi tapi sejak beberapa tahun terakhir mengajar sablon di Wedi untuk orang dari luar Wedi dan bahkan mengajar sablon ke luar Wedi. Freedom mempunyai kapasitas kerja 72 papan. Dibandingkan unit sablon lain memang sedikit, biasanya berjumlah sekitar 108 atau lebih. Jumlah yang lebih sedikit dibandingkan unit lain karena kapasitas ruang yang dimiliki hanya bisa untuk 78 papan. Seperti unit sablon lainnya area kerja sablon dibuat dari tembok bata dan bagian atap tidak menggunakan plafon. Atap dibuat dengan menggunakan atap galvalum yang ringan dan lebih mampu meredam panas. Sirkulasi udara juga cukup baik karena area kerja sablon dibuat semi terbuka.

Ketebalan papan triplek yang digunakan sebagai landasan sablon pada umumnya sekitar $40 \times 50 \mathrm{~cm}$ dengan kapasitas area sablon setara dengan kertas A3. Jika ada ukuran papan yang beda biasanya lebih besar dipakai untuk area sablon lebih besar. Sablon dilakukan diatas bahan yang belum dijahit masih berbentuk pola. Proses pemotongan di unit sablon Freedom dilakukan sendiri oleh Agus Nugroho.

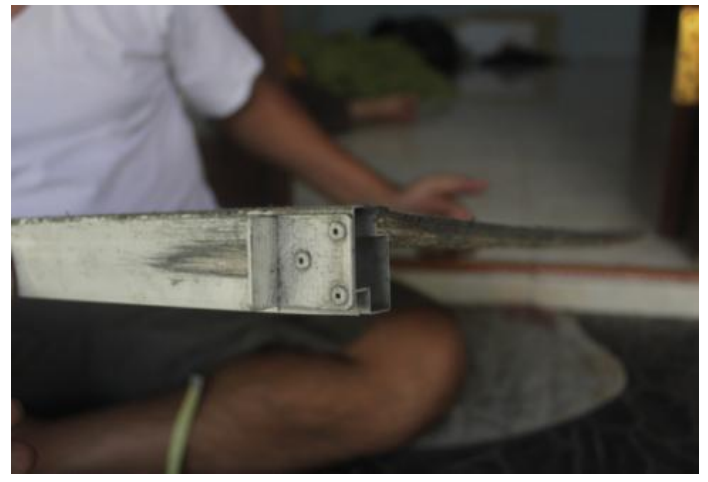

Gambar 1. Detail papan renteng yang menjadi khas meja sablon di Wedi

Meja sablon di Wedi yang umumnya menggunakan papan renteng sekaligus berfung si sebagai register atau disebut kento dalam cetak tinggi. Triplek yang digunakan adalah landasan untuk menyablon. Alumunium yang ada di papan merupakan register. Ukuran yang ada. Ada dua jenis papan yang dimiliki Agus Nugroho yaitu papan renteng enam dengan ukuran masing-masing $40 \times 50 \mathrm{~cm}$ dan papan lepasan untuk media sablon lebih besar ukuran $45 \times 60 \mathrm{~cm}$.

Papan bisa dipesan di Klaten. Ada dua tempat atau toko besi yang bisa membuatkan. Tampak padabagian bawah papan lepasan diberi penguat sehingga tidak bergoyang saat proses gesut. Papan sebagai register juga mempermudah saat proses sablon multi warna. Pengepasan sudah dimulai sejak proses penyinaran. Semua film dibuat satu ukuran begitu juga screen dibuat satu ukuran. Untuk menggukur area film di screen menggunakan papan pengukur. Papan itu dibuat seukuran dengan papan renteng atau lepasan yang diberi ukuran seperti penggaris dan dilapisi plastik.

Untuk register pada screen diberi paku yang biasa digunakan dan mudah didapat. Masing-masing screen terdapat dua register. Register yang berupa paku hook diletakkan diujung screen. Jika saat mulai 
proses gesut ternyata kurang presisi maka register bisa dicabut dan dipasang sesuai kebutuhan tanpa membutuhkan alat khusus dan dengan waktu yang singkat.

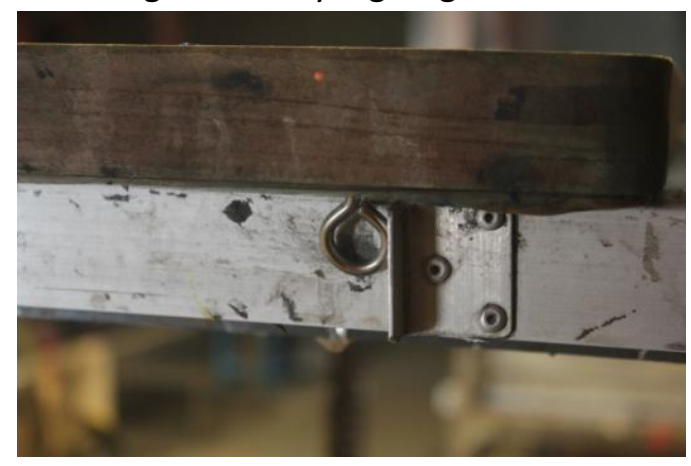

Gambar 1. Pengepasan screen dan papan dengan register pada screen dan papan

Di unit sablon Freedom rangka meja sablon dibuat dari alumunim dengan ukuran panjang $270 \mathrm{~cm}$, lebar $120 \mathrm{~cm}$ tinggi $85 \mathrm{~cm}$. Terlihat meja dibuat renteng 6 karena panjang alumunium yang jika lebih dari 3 meter cenderung. Area penyimpanan cat, biang warna dan emulsi menjadi satu.Untuk cat yang sudah dicampur biang warna disimpan dalam wadah yaitu gelas plastik yang mempunyai tutup. Gelas juga dipakai sekaligus sebagai tempat mencampur warna dengan biang cat. Di unit sablon Freedom bahan cat serta biang warna menggunakan buatan lokal biasanya dibeli di sekitar Wedi atau di Yogyakarta.

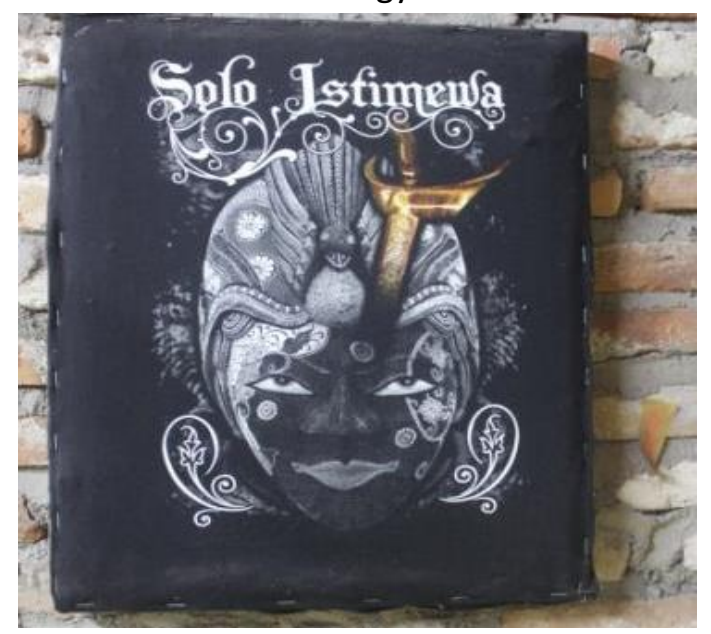

Gambar 3. Hasil sablon dengan teknik cecak di Unit Sablon Freedom
Contoh hasil sablon yang pernah dibuat Agus Nugroho. Terlihat motif cecek atau pointilis yang dibuat dengan menggunakan software komputer. Sebagian besar kaos yang dibuat di Wedi adalah pesanan dari luar Klaten, biasanya Jawa Timur bahkan ada yang berasal dari Papua dan Kalimantan.

Desain sebagian besar berasal dari pemesan, biasanya berupa softcopy yang kemudian diproses di komputer untuk dibuat film yang disebut setting. Semua desain melalui proses setting di Komputer. Proses setting bisa sederhana jika desain yang diterima sudah berupa file vektor. Desain yang telah melewati tahap setting dicetak dengan alat cetak elektronik yang biasa disebut printer jenis inkjet. Cat printer inkjet yang cair memang mudah didapat tapi mempunyai kelemahan pada warna yang kurang pekat serta mudah luntur saat kertas diolesi minyak. Pengolesan minyak pada kertas bertujuan agar kertas menjadi bersifat transparan untuk dibuat film. Ini dilakukan selain ekonomis juga karena mencetak desain menggunakan media khusus yang transparan tidak ekonomis dan tidak mudah didapatkan di daerah seperti wedi. Untuk menghindari luntur biasanya hasil cetak dari komputer di fotocopy. Kepekatan warna pada mesin foto kopi yang menggunakan cat bubuk sesuai dengan kebutuhan untuk membuat film. Desain yang sudah difotokopi menggunakan kertas HVS harus dibuat transparan untuk proses penyinaran.

Proses setting menjadi agak sulit jika file desain berupa foto. Untuk mengolah file foto menggunakan software pengolah omage berbasis bitmap. Sebelum marak penggunaa komputerdi wedi, setting untuk membuat film multi warna menggunakan meja penyinaran yaitu gambar ditracing. 
Sedangkan efek cecek yang sudah menjadi khas Wedi sejak beberapa tahun yang lalu dibuat menggunakan opaque atau spidol. Saat ini teknik cecek tidak dibuat karena tidak ada permintaan.

Agus Nugroho mulai mengerjakan teknik sablon dengan film yang menggunakan settingan komputer sejak lima tahun yang lalu. Untuk proses settingan yang sederhana sudah bisa dikerjakan sendiri tapi untuk proses yang lebih rumit dikerjakan oleh jasa setting yang sudah ada di Wedi. Kemampuan menggunakan komputer didapat secara otodidak sehingga ketrampilan penggunaan komputer juga terbatas. Untuk pengerjaan desain atau setting yang lebih rumit seperti pisah warna Agus Nugroho menggunakan jasa setting yang mulai marak di Wedi.

Unit Sablon yang lain yaitu Hikaru adalah milik Ali, sekretaris Paguyuban Kampung Sablon dengan nama Hikaru. Unit sablon milik Ali sudah dilengkapi dengan konveksi. Seperti unit sablon yang lainnya area kerja Hikaru menjadi satu dengan rumah tinggal. Area sablon berada di lantai atas rumah sedangkan konveksi atau area jahit dibagian bawah.

Seperti halnya freedom unit sablon dibuat terbuka. Rak penyimpanan screen sekaligus area menjemur screen diletakkan di area yang lebih terbuka. Rak penyimpanan screen seperti rata-rata unit sablon di Wedi dibuat dengan alumunium bertingkat tiga.Jumlah screen di Hikaru lebih banyak dari rak yang tersedia. Hal tersebut juga memperlihatkan perkembangan studio. Biasanya screen yang sedang digunakan atau masih dalam proses tidak diletkkan di rak. Selama gambar belum rusak atau screen masih belum digunakan untuk pengerjaan lain, film masih belum dihapus karena ada beberapa desain yang kadang dipesan ulang.
Terlihat meja penyinaran dibuat sesuai dengan ukuran maksimal screen yang ada yaitu A2. Bekas film berupa kertas HVS yang diberi minyak sayur diletakkan disebelah meja penyinaran.. Di Hikaru karena meja penyinaran diletakkan di area terbuka penyinaran lebih sering dilakukan menggunakan sinar matahari.

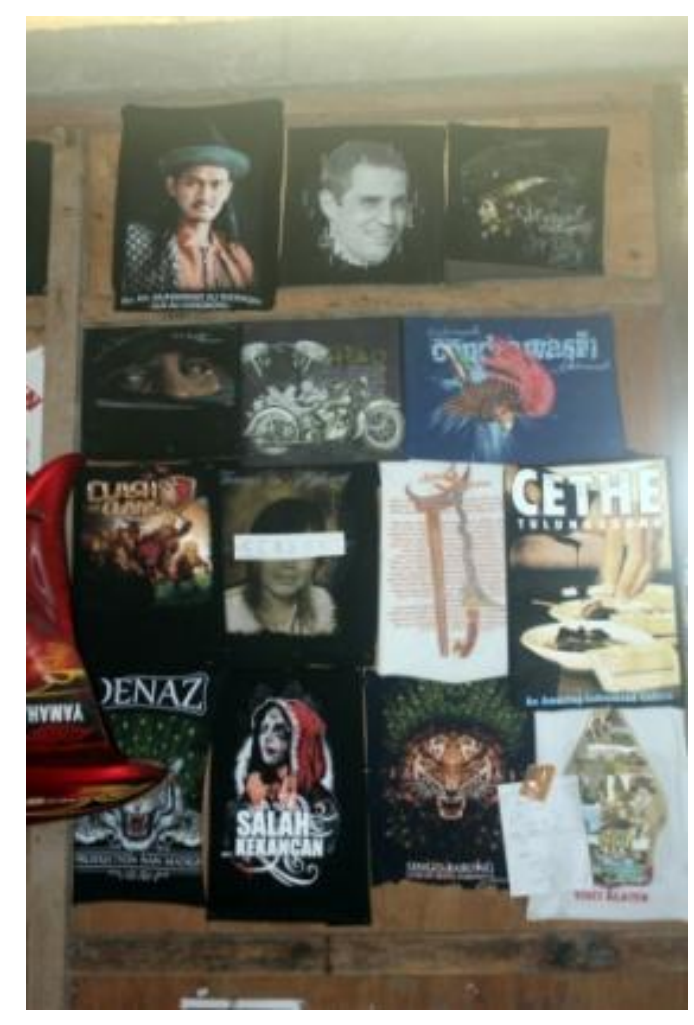

Gambar 4. Contoh hasil sablon di Unit Sablon Hikaru

Hampir semua unit sablon di Wedi memajang hasil sablon mereka di tembok. Pemajangan hasil sablon di Hikaru memperlihatkan banyak desain menggunakan media kaos hitam. Terlihat penggunaan foto dalam desain yang membutuhkan setting komputer mulai banyak. Pemilik Hikaru sendiri mengatakan untuk proses setting dilakukan sendiri jika yang mudah tapi jika susah menggunakan jasa setting.

Seperti unit sablon lain di paguyuban area kerja hanya berupa tembok 
bata dan lantai plester semen. Pada meja renteng yang menempel di tembok dan papan dibuat rangkap dua. Papan renteng berjumlah masing-masing enam dengan ukuran papan $40 \times 50 \mathrm{~cm}$ dan ada papan lepasan dengan ukuran $45 \times 60 \mathrm{~cm}$. Rangka meja dibuat dari alumunium siku denga ukuran $270 \times 110 \times 85 \mathrm{~cm}$.

Unit sablon di Wedi rata-rata membuat area kerja sablon yang tidak membutuhkan banyak lampu karena ruangan yang semi terbuka, kecuali jika harus bekerja sampai malam. Penggunaan energi listrik yang minim juga terlihat pada proses pembersihan screen yang tidak menggunakan alat semprot bertekanan. Area mencuci screen umumnya hanya mengandalkan tandon air tanpa ada alat penyemprot bertekanan. Cukup dengan selang dan air yang mengalir screen bisa dibersihkan. Untuk membesihkan screen seperti pada unit sablon lain tidak menggunakan pembersih yang bermerk tapi dengan campuran kaporit, detergen dan soda api. Bahkan untuk menghilangkan bayangan warna pada screen bisa ditambah dengan abu gosok.

Pesanan kaos yang diterima banyak dari Jawa Timur. Sebagian besar media adalah kaos berwarna hitam. Penggunaan kaos berwarna hitam sendiri membutuhkan proses lebih panjang dibanding kaos berwarna terang. Sebelum disablon sesuai desain kaos hitam harus disablon warna putih yang dibuat sesuai desain. Warna putih membutuhkan pross sablon dua kali agar menghasilkan warna rata dan muncul.

Hasil sablon yang menggunakan setting di komputer dengan menggunakan software berbasis bitmap biasa disebut simulated spot colour, efek menyerupai menggunakan film separasi. Salah satu unit sablon di Wedi, Warning mulai banyak menerima jasa sablon yang untuk proses setting desainbanyak menggunakan software berbasis bitmap

Untuk proses kerja menggunakan meja jenis renteng yang bergerak adalah penyablon berbeda dengan meja putar dimana penyablon cukup berdiri dan meja yang bergerak. Tempat penyimpanan screen terbuat dari alumunium tingkat 2 . Seperti semua unit sablon di Wedi, area penyimpanan screen dibuat dengan rak sehingga tersusun rapi walau penambahan jumlah screen kadang belum diikuti dengan penambahan jumlah rak.

\section{PENUTUP}

Semangat kebersamaan yang dibangun dalam Paguyuban Kampung Sablon tidak hanya dalam tahap menjalankan usaha tapi juga pada berbagai aspek yang besifat teknis salah satunya adalah membagi kemampuan menyablon. Terlihat pada kemampuan sablon para anggota paguyuban yang didapat secara otodidak tidak melalui sekolah seni atau kursus. Pola seperti ini membuat penggunaan alat dan bahan yang sama pada semua unit sablon di Wedi.

Paguyuban juga sebagai wadah untuk bertukar informasi mengenai teknis, alat dan bahan. Paguyuban juga mendorong karyawan yang telah lama bekkerja sebagai tukang sablon dan telah menguasai teknis sablon utnuk membuka jasa sablon sendiri. Terlihat dari jumlah anggota paguyuban yang telah bertambah dari 9 pada awal didirikan sekarang menjadi 15 unit sablon.

Cara kerja unit sablon hampir sama semua karena memang tidak ada kompetisi negatif. Bahkan jika ada yang kewalahan menerima order diberikan ke unit sablon lain. Kondisi tersebut membuat alat dan 
bahan yang digunakan mempunyai kesamaan yaitu:

1. Penggunaan register untuk meja sablon berupa triplek renteng 6 dengan ukuran standar $40 \times 50 \mathrm{~cm}$ serta hook sebagai register.

2. Bahan yang digunakan berupa cat rubber, tidak menggunakan bahan terbaru yang membutuhkan penambahan alat seperti cat plastisol

Rekayasa dilakukan untuk mencapai hasil yang lebih baik dan kerja yang lebih efisien. Rekayasa yang dicapai adalah pada bentuk triplek renteng 6 yang bias disusun menjadi 2 seri. Ukuran triplek ada dua jenis yaitu $40 \times 50 \mathrm{~cm}$ dan $45 \times 60 \mathrm{~cm}$. Jika dibanding dengan meja renteng di tempat lain memang sepintas tidak berbeda tetapi ada sedikit perubahan pada alumunium yang dipasang di papan triplek pada papan lepasan yang diberi tambahan penguat.

Unit sablon wedi cenderung melakukan kerja secara sederhana tanpa bantuan alat yang menggunakan listrik sehingga untuk proses mencuci screen tetap manual tidak menggunakan alat semprot dengan tekanan tinggi. Kondisis ini membuat mereka mempunyai area cuci yang dimodifikasi dengan tandon yang langsung berada diatasnya.

Unit sablon di Wedi serta Klaten umumnya terkenal dengan teknik cecak ataupointilis. Ciri khas ini sekarang tidak dipergunakan lagi karena memang semua unit sablon di Wedi adalah jasa sablon sehingga sablon yang dihasilkan mengikuti keinginan pemesan yang cenderung sesuai dengan trend. Kemampuan untuk menyablon diatas kaos warna hitam dengan rapi membuat banyak pesanan yang diterima adalah kaos warna hitam.

Semua unit sablon, terutama pemilik dalam 15 tahun terakhir telah mengembangkan kemampuannya dengan melakukan proses setting dengan komputer. Kemampuan yang dimiliki diperoleh secara otodidak tanpa melalui kursus. Penggunaan komputer dalam proses setting sebuah unit sablon saat ini menjadi satu bagian yang tidak dapat dipisah walau mulai muncul usaha jasa setting di Wedi.

Walau sepintas kualitas dan kemampuan sablon terlihat sama, sebenarnya masing-masing unit punya kelebihan. Misal untuk Hikaru yang mempunyai konveksi lebih banyak menerima jasa membuatkan seragam untuk sekolah, jumper yang memang banyak kombinasi jahit dibanding kaos oblong. Untuk unit sablon tanpa konveksi seperti Freedom, Warning dan Seize The Day banyak menerima kaos oblong yang memang desain dan setting lebih rumit dibandingkan seragam. Masing-masing juga sudah mempunyai pelanggan yang berbeda selera.

\section{Daftar Pustaka}

Adam, Robert dan Robertson, Carol, Screen Printing The Complete Waterbased System, Thames and Hudson, Ltd, London 2003

Barker, Chris, Cultural Studies: Teori \& Praktik, Kreasi Wacana, Yogyakarta, 2004

Heller, Jules Printmaking Today, Holt, Rinehart \& Winston Inc. New York, 1967

Ratna, Nyoman Kuntha, Metodologi Penelitian, Kajian Budaya Dan IImu Sosial Humaniora Pada Umumnya, Yogyakarta, Pustaka Pelajar, 2010

Ragans, Rosalind, Ph.D.Art Talk, Fourth Edition, MacGraw Hill, California, 2005 
54 ] CORAK Jurnal Seni Kriya Vol. 6 No.1, Mei-Okteber 2017

Roni Henning, Screen Printing Water Based Techniques, Watson Guptil Publications, New York, 1994

Stembery, Harry, Silk Screen Color Printing, Mc. Graw Hill Book Co, New York, 1971

Saff, Donald and Scacilotto, Deli, Printmaking, History And Process, Holt Rinehart and Winston, New York, 1978

Internet:

www.kampung-sablon.blogspot.com 